\title{
Brazilian attorneys demand abortion rights for women infected with Zika
}

\author{
Cláudia Collucci
}

São Paulo

A public attorneys' association has asked Brazil's Supreme Court to allow women who have contracted the Zika virus and are in a state of "great mental suffering" to have access to abortions.

Under Brazilian law, abortion is permitted only in cases of rape, when there is a threat to the mother's life, or if the fetus has anencephaly.

The petition, which was delivered on 24 August, proposes that the mental suffering of pregnant women seeking abortions must be verified by medical and psychological reports. "[Abortion] would only occur in very exceptional cases," said Joaquim Neto, president of the National Association of Public Defenders.

The guiding principle of the demand is women's rights to dignity, healthcare, and freedom from psychological torture, which are enshrined in Brazil's 1988 constitution.

Neto said, "Abortion is not the main goal of the petition, but it is impossible to talk about Zika without addressing abortion. We have a public health emergency affecting the most vulnerable people, who face a silent state in relation to public policies," said Neto.

The attorneys argue that the Zika epidemic is a result of the state's failure to control the spread of the Aedes aegypti mosquito.

Debora Diniz, the anthropologist leading the campaign, said, "The Brazilian government is indeed at fault for not having been able to stop the disease from spreading.

"Pregnant women are suffering a serious violation by the state. Some women have seen their childbearing dreams turned into nightmares because of the Zika virus."

The petition also called for accessible and affordable contraception and health and social support for women who choose to keep their baby. Diniz said that women were worried about how they would care for their disabled children.

The petition also asked for changes to Brazil's rules on social assistance, which currently limit financial benefits for families with babies with microcephaly and other neurological disorders to three years. "The disability of these children is permanent," said Neto.

Since October 20151806 confirmed cases of a neurological syndrome associated with infection with the Zika virus in Brazil and 2978 suspected cases have been reported, up from fewer than 150 cases in the whole of $2014 .^{1}$

A poll conducted in February found that a majority of the Brazilian population (58\%) did not support the right to abortion for women infected with Zika. Even in cases of microcephaly $51 \%$ rejected access to legal abortion. ${ }^{2}$

Access to birth control and abortion are issues in many of the 20 or so countries in Latin America affected by Zika virus. Some, such as El Salvador and Ecuador, have restrictive abortion laws similar to that in Brazil. In 2012 Uruguay became only the second country in Latin American, after Cuba, to decriminalise abortion. $^{3}$

Demand for abortions has soared among women in countries affected by the Zika outbreak, ${ }^{4}$ with a surge in requests to a website that helps women obtain pills to terminate pregnancy in countries where abortion is illegal. In Brazil, Venezuela, and Ecuador requests for help have doubled in recent months. For example, there were 1210 requests for abortion pills from women in Brazil between November 2015 and March 2015, more than double the 582 expected.

1 Centro de Operações de Emergências em Saúde Pública sobre Microcefalias. Monitoramento dos Casos de Microcefalia no Brasil: informe epidemiológico No 38. http: //combateaedes.saude.gov.br/images/sala-de-situacao/informe microcefalia epidemiologico38.pdf

2 Instituto Datafolha. Opinião sobre vírus Zika: fevereiro de 2016. http://media.folha.uol. com.br/datafolha/2016/02/29/zika.pdf

3 Guttmacher Institute. Abortion in Latin America and the Caribbean: fact sheet. https:// www.guttmacher.org/sites/default/files/factsheet/ib_aww-latin-america.pdf

4 Aiken ARA, Scott JG, Gomperts R, Trussell J, Worrell M, Aiken CE. Requests for abortion in Latin America related to concern about Zika virus exposure. $N$ Engl $J$ Med 2016;375:396-8. doi:10.1056/NEJMc1605389 pmid:27331661.

Published by the BMJ Publishing Group Limited. For permission to use (where not already granted under a licence) please go to http://group.bmj.com/group/rights-licensing/ permissions 